\title{
Hunger AND THE ClericAl CANINE: THE DOG AS METAPHOR IN PIERS PLOWMAN B
}

\section{Rosanne Gasse}

Hunger in Piers Plowman $B$ is a controversial and perplexing figure in passus 6 , one that has garnered considerable and remarkably divergent critical attention over the years. Past studies of Hunger in Piers Plowman have split into those who favor the episode's social critique of poverty and the greater labor issues which it implies-Derek Pearsall, for instance, who even phrases his discussion within the terms of a modern welfare state $^{1}$ - and those who, while they may acknowledge the literal aspect of physical hunger in the scene, prefer to emphasize its allegorical implications. D. W. Robertson, Jr. and Bernard Huppé, most famously, spend a mere eleven lines on the literal meaning of Hunger, but more than eight pages of analysis on their allegorical/tropological exegesis in which Hunger is revealed to be "the lack of spiritual food in forgetfulness of the creator." 2 Certain scholars also have noted the profound instability

\footnotetext{
1 "Piers Plowman and the Problem of Labour" in The Problem of Labour in FourteenthCentury England, ed. James Bothwell et al. (York: York Medieval Press, 2000), 125-26. Others who emphasize the social aspects of the scene, especially as a critique of fourteenthcentury labor legislation, include Britton J. Harwood, Piers Plowman and the Problem of Belief (Toronto: University of Toronto Press, 1992), especially at 150; Margaret Kim, "Hunger, Need and the Politics of Poverty in Piers Plowman," Yearbook of Langland Studies 16 (2002), 131-68; and Kate Crassons, The Claims of Poverty: Literature, Culture, and Ideology in Late Medieval England (Notre Dame: Notre Dame University Press, 2010), 30-40. Ralph Hanna takes a particularly bitter stance, accusing Hunger of "cynically us[ing] learned biblicism to support an almost Malthusian scientism" (London Literature: 13001380 [Cambridge: Cambridge University Press, 2005], 283).

2 D. W. Robertson, Jr., and Bernard Huppé, Piers Plowman and Scriptural Tradition (New York: Octagon Books, 1969), 84. In Robertson and Huppé's tradition follow such scholars as Katherine Trower, "The Figure of Hunger in Piers Plowman," American Benedictine Review 24, no. 2 (1973), 238-60, for whom the point of the episode is spiritual hunger and the need to reinstate the penitential life; John Bowers, The Crisis of Will in Piers Plowman (Washington, D.C.: Catholic University of America Press, 1986), 123-27, for whom the pilgrims on the half-acre are the slothful Israelites wandering in the desert; and Kathleen Hewett-Smith, "Allegory of the Half-Acre: The Demands of History," Yearbook of Langland Studies 10 (1996), 1-22. Less directly in this tradition is Jill Mann in "Eating and Drinking in Piers Plowman," Essays and Studies 32 (1979), 26-43. Mann relegates Hunger to the literal level, the beneficial role of driving men to work (and bringing up for discussion the question of justice in the world, it would seem) and reserves the spiritual significance for the later figure of Need. In the end, however, she pulls the two concepts firmly together: "God is driven by a need which is as concrete, as impossible to paraphrase, as the need of hunger or thirst" (42). Nicolette Zeeman, who discusses Need at
} 
of Hunger's message as a character. David Aers points out the "wobble" between Hunger's moral justification of solutions centered on hunger and forced labor on the one hand, and Hunger's abandonment of the punitive surveillance involved in discriminatory and disciplinary charity on the other. ${ }^{3}$ C. David Benson likewise notes that Hunger sometimes speaks like a "pitiless Simon Legree" but then can suddenly switch his discourse to that of a caring "St. Francis." Benson's conclusion sums up neatly the confusion felt by the many critics who expect to find a single, straightforward meaning in B passus 6: "The Hunger episode provides no clear lesson - or rather too many. No single voice or position dominates for long, as Hunger is explored from multiple perspectives."4

This article will argue for a new and significant metaphorical approach to understanding the code-switching wobble evident in the figure of Hunger in B passus 6. It will posit that Hunger is meant to be recognized as Piers's watchdog who comes running to the attack the instant his master calls. Shortly before Piers calls upon Hunger for help against Waster and the boastful Bretoner, wasters are declared to be "wolveskynnes." 5 This lupine metaphor segues into the canine one which follows, because having to deal with predatory wolves on the property is a farming situation which any medieval person would understand needed a dog to be present. The dog was - and is - an animal that would have been familiar to readers of the fourteenth century as a valuable working animal and that from truly ancient times had secured its position as man's best friend, the animal always in human company. Indeed, the hound's status itself is not unlike that of the specter of Hunger, which also is a constant companion, an ever present reality for the human condition throughout history.

Evidence in support of this metaphorical canine supposition includes the vocal manner in which Piers summons Hunger. Piers

length, but ignores Hunger, follows in this vein in her book Piers Plowman and the Medieval Discourse of Desire (Cambridge: Cambridge University Press, 2006), 274-81.

${ }^{3}$ David Aers, Community, Gender, and Individual Identity: English Writing 1360-1430 (London \& New York: Routledge, 1988), 45.

${ }^{4}$ C. David Benson, Public Piers Plowman: Modern Scholarship and Late Medieval Culture (University Park: Penn State Press, 2004), 139.

${ }^{5}$ B.6.161. All references are to the B text of Piers Plowman unless otherwise indicated. Citations are from William Langland, Piers Plowman: A Parallel-Text Edition of the A, B, $C$ and $Z$ Versions, Vol. I: Text, ed. A. V. C. Schmidt (London and New York: Longman, 1995) unless they are specifically said to be from the Athlone A-text edition prepared by George Kane or the Athlone B-text edition prepared by Kane and E. Talbot Donaldson. 
"houped after Hunger, pat herde hym at pe firste" (6.172). Houped is strongly suggestive that Piers is calling after some sort of animal, given its common usage as found elsewhere in Middle English literature. In the Parlement of the Thre Ages, for instance, the hunting hawks are called to their prey by the hunter who "quopes thaym to the querrye that quelled hym to the dethe." "In Chaucer's Nun's Priest's Tale, this same whooping sound is heard as the barnyard's denizens pursue the fox:

So hydous was the noyse, $-\mathrm{a}$, benedicitee! -

Of bras they broghten bemes, and of box,

Of horn, of boon, in whiche they blewe and powped,

And therwithal thay skriked and they howped. ${ }^{7}$

The sound is heard again as a sheep call in the First Shepherd's Play of the Towneley Cycle: "What, whyll thou not yit / I say, let the shepe go? Whop!" ${ }^{8}$ In the morality play Mankind, the whooping sound is expressly heard in relation to a running dog - or at least a figurative one when the vice New Guise exclaims of Mankind dressed in his fine new jacket his resemblance to a greyhound: "Hay, doog! Hay, whoppe! whoo! Go yowr wey lightly! / Ye are well made for to ren." 9 And in one instance elsewhere in Piers Plowman itself, or at least in Schmidt's edition of it, the only response that the begging poor at the outside gate receive from the feasting rich within is to be "hoen on hym as an hound and hoten hym go pennes" (10.61). ${ }^{10}$

${ }^{6}$ Wynnere and Wastoure and The Parlement of the Thre Ages, ed. Warren Ginsberg (Kalamazoo: Medieval Institute Publications, 1992), Parlement of the Thre Ages, line 233.

${ }^{7}$ Geoffrey Chaucer, "The Nun's Priest's Tale" from The Canterbury Tales, in The Riverside Chaucer, 3rd edition, ed. Larry D. Benson (Boston: Houghton Mifflin, 1987), VII 3393, 3398-3400.

8 The Towneley First Shepherd's Play, in The Towneley Plays, ed. George England and Alfred W. Pollard (Reprint, London: Oxford University Press, 1966), lines 118-19.

${ }^{9}$ Mankind, in Medieval Drama, ed. David Bevington (Boston: Houghton Mifflin, 1975), lines 720-21.

${ }^{10}$ In the 1975 Athlone B edition, Kane and Donaldson read "But [hunsen] hym as a hound and hoten hym go pennes" (10.62). Schmidt's "hoen on" is the reading found in two B-text manuscripts, RF, while "hunsen" is not recorded in any B-text manuscript. Other B manuscripts read variously "hunten" (WHmCrM), "heon on" (GYCL), "howen on" (OC ${ }^{2}$ ), and "howlen on" (BmBoCot). "Hunsen" is the A-text reading at the equivalent point, A.11.48, upon which Kane in the 1960 Athlone A edition and Schmidt in the 1995 Longman edition agree. 
Further textual evidence supporting Hunger's particularly canine violence may be found in the damage inflicted on the bodies of the Bretoner and Waster, which is consistent with being attacked by a dog, either seized in the jaws and violently shaken to and fro or knocked to the ground and buffeted by the paws. The number of cures for dog bites listed in the Old English Herbarium and the moral exempla used of biting dogs which are found in collections such as Aesop's Fables and the fourteenth-century preacher's manual Fasciculus Morum would suggest that dog attacks were not at all uncommon in premodern times. Especially significant is that Piers must call Hunger off the attack by offering him a "pese loof" to chew upon instead, "pese loof" being a sort of bread made from dried peas and likely the same as the "houndes breed" to which Hunger later refers at 6.214. Trying to divert a dog's attention with a piece of bread is an animal-control technique so old and well-known that it is referenced as far back as Aesop. ${ }^{11}$

The particulars of Hunger's attack itself are as follows in the B edition:

Hunger in haste poo hente Wastour by pe mawe

And wrong hym so by pe wombe pat al watrede hise eizen.

He buffetted pe Bretoner aboute pe chekes

That he loked lik a lanterne al his lif after.

He bette hem so bope, he brast ner hire guttes;

Ne hadde Piers wip a pese loof preyed hym bileue,

They hadde be doluen bope - ne deme pow noon ooper.

(6.174-80)

"Mawe" at line 174 is usually glossed as referring to Waster's own stomach, because hunger is felt most particularly in the guts. ${ }^{12}$ But according to the Middle English Dictionary, ${ }^{13}$ "mawe" can also mean the jaws or the throat, in which sense it can equally apply to Hunger who, like a dog, seizes Waster in his ever-voracious maw, clamps down, and

${ }^{11}$ Fables of Aesop, ed. and trans. S. A. Handford (Harmondsworth: Penguin, 1964), fables \#124, 128. A more literary example with a happier result for the transgressors is the case of the Sybil in Vergil's Aeneid who throws Cerberus a drug-laced cake drizzled with honey so that she and Aeneas may slip past the watchdog of Hades. See P. Vergili Maronis Aeneidos, Liber Sextus, ed. R. G. Austin (Oxford: Clarendon Press, 1977), 6.420-21.

${ }^{12}$ So George Kane, Piers Plowman: Glossary (London and New York: Continuum, 2005), 134; Schmidt, line gloss to 6.174 in his 1995 Everyman 2nd edition (London, J .M. Dent), 103.

${ }^{13}$ Middle English Dictionary," maue" n. 3. "The jaws; throat, gullet" M.2.228. 
vigorously shakes his prey. Either way, the concrete particulars of the imagined attack are loose, fantastical, and entirely appropriate to maintaining an already established canine metaphor: to be able to "wring" Waster out by the womb, which is a metaphor of applied force that actually derives from laundry practice, Hunger needs to be truly large in size; and a huge dog shaking Waster in its maw makes as much sense as a gigantic human squeezing him in his hands. Langland simply allows the ambiguity of the visual language to speak: Hunger grips Waster by the stomach when he seizes his prey in his enormous maw and bites down.

But to understand why Langland would have chosen such a seemingly bizarre figuration as a talking hound for Hunger we need first to grasp the literal and metaphorical significance of the dog within the general frame of reference of medieval literature. The dog or, to use the more common Middle English generic term hound, is frequently referred to in medieval texts because it was a working animal instrumental in dayto-day life in the Middle Ages, particularly useful for hunting. This straightforward role for the dog is evident in texts such as Sir Gawain and the Green Knight and the Parlement of the Thre Ages in which hunting scenes are common. ${ }^{14}$ The contemporary practice of keeping a dog as a pet is rarer, but not unknown in medieval texts. In The Seven Sages of Rome, for example, a wife kills her husband's favourite lap dog, a "lytel kenet," because it urinated on her dress, and Chaucer's Prioress of course keeps her pampered "smale houndes" well fed. ${ }^{15}$ In Piers Plowman, the dog appears as a working animal, such as the gleeman's trained bitch (5.347) or the hunting hound (10.308). Being such a common animal in the medieval experience made it possible for the canine to accrue a wide range of traditional associations and familiar symbolic meanings, both good and bad. ${ }^{16}$

\footnotetext{
${ }^{14}$ See for instance, lines 1697-1728 in Sir Gawain and the Green Knight; lines 39 and 60 in The Parlement of the Thre Ages.

15 The Seven Sages of Rome (Midland Version), ed. Jill Whitelock (Oxford: Oxford University Press, 2005), lines 1740-49; Chaucer, General Prologue to The Canterbury Tales, I 146-47.

${ }^{16}$ For a quick survey of references to dogs, good and bad, in medieval texts as well as in late classical authors such as Augustine, Gregory the Great, and Caesarius of Arles, see Alberto Ferreiro, Simon Magus in Patristic, Medieval and Early Modern Traditions (Leiden: Brill, 2005), 155-81. Another survey of medieval references to good and bad dogs and especially intriguing for its argument that "the dog became an important symbol for the
} 
In the negative, being called a son of a bitch is an insult of longstanding and as such it is used as a by-word for the ungrateful adult child in the fourteenth-century preacher's handbook Fasciculus Morum. ${ }^{17}$ The villainous Saracens of the romance King Horn are disparaged as "heathen hounds" while the noble Havelok in Havelok the Dane must defend himself from common ruffians who are likened four times to dogs. ${ }^{18}$ Langland too can be seen to participate in this negative frame of reference when the poor are insulted as hounds (10.62). Yet while the negative aspect of the dog can be tracked back to its folkloric association with the underworld in both classical and Celtic/Germanic myth, often making the hound in the medieval imagination a potent figure for the demonic, ${ }^{19}$ Langland does not seem engaged with this strongly negative canine tradition. Nor does he emphasize the dog's common association with immoderate sexual appetite as seen, for example, in Fasciculus Morum which describes incest as an act that "makes a man like a dog who pays no attention to his blood relationships when it comes to sex" any humor the stratagem of the weeping bitch, starved then fed pepper by an old bawd to cause the tears that will dupe a foolish girl into giving up

religious conflict between Jews and Christians" (70) is that of Irven M. Resnick in "Good Dog/Bad Dog: Dogs in Medieval Religious Polemics,” Enarratio 18 (2013), 70-97.

17 Fasciculus Morum: A Fourteenth-Century Preacher's Handbook, ed. and trans. Siegfried Wenzel (University Park: Penn State Press, 1989), 89.

${ }_{18}$ King Horn, line 602; Havelok the Dane, lines 1839, 1883, 1922, and 1967. Both texts are included in Middle English Verse Romances, ed. Donald Sands (Exeter: University of Exeter Press, 1986).

${ }^{19}$ See for instance, the several references to hell hounds provided by Morton Bloomfield in his classic study, The Seven Deadly Sins: An Introduction to the History of a Religious Concept, with Special Reference to Medieval English Literature (Ann Arbor: Michigan State University Press, 1952), 131, 145, 149, 151, 187, 205, and 231.

${ }^{20}$ Fasciculus Morum, 683. Fasciculus Morum also recounts the following tale of a lecher and his concubine who ignore the holiness of the Feast of All Saints to indulge in the sexual act: "But lo, in punishment they were both strangled by the devil before completing the act; and on the following day they were found by their neighbours joined together like a couple of dogs, horrible to see and smell, and nobody could go near them for the stench. Then their neighbours tied their feet to the tails of horses and they were pulled out of their village and cast into a dirty pit and left there, where they were immediately consumed by fire from hell" (695). Yet another example comes from Chaucer's Parson's Tale in which, under the description of Lechery, "thise olde dotardes holours, yet wole they kisse, though they may nat do, and smatre hem. / Certes, they been lyk to houndes; for an hound, whan he comth by the roser or by othere bushes, though he may nat pisse, yet wole he heve up his leg and make a contenaunce to pisse" (Fragment X, lines 856-57). 
her virginity to a lecherous cleric. ${ }^{21}$ Langland in contrast chooses to frame the dog's sexual behaviour as a signifier of the utmost moral probity when he expresses admiration for its upright conduct as an animal that will not engage in inappropriate sexual intercourse with a pregnant bitch (11.342-43).

Yet if Langland downplays the dog's negative association with sexual appetite as often depicted by other authors of the time period, he will prove to be in full accord with another traditional construct developed around the dog as a figure of carnal, physical excess. The dog's longstanding association with the voracious consumption of food is important as another piece of the puzzle that reveals Hunger's canine identification in Piers Plowman. ${ }^{22}$ The Fasciculus Morum twice cites Psalm 58:7, an influential biblical text in which gluttons are said to "suffer hunger like dogs" and which describes what Fasciculus Morum terms the "dog-like appetite which hardly ever gets quenched." ${ }^{23}$ Another instrumental biblical text on the carnal nature of dogs is Proverbs 26:11 (repeated in 2 Peter 2:22), the source of a familiar trope in the Middle Ages: the dog that returns to eat its own vomit. In both Fasciculus Morum and the Bestiary, this dog-like act, familiar enough from common observation, is interpreted as backsliding, falling back into disgusting old behaviors after confession. ${ }^{24}$ Langland too, of course, invokes the dog-to-

21 The weeping bitch is an ancient and familiar story. It is given, for instance, a humorous rendition in the fabliau Dame Sirith and appears in Aesop's Fables. For some background on the story, see Gillian Adams, "A Medieval Storybook: The Urban(e) Tales of Petrus Alfonsi," Children's Literature Association Quarterly 23, no.1 (1998), 7-12, especially at 10; Edelgard DuBruck, “Aesop's Weeping Puppy: Late Medieval Migrations of a Narrative Motif," The Early Drama, Art, and Music Review 22, no.1 (1999), 1-10; and Stewart Justman, "The Secularism of Fiction: A Medieval Source," Literary Imagination 10, no. 2 (2007), 127-41, especially at 138-39.

${ }^{22}$ Benson refers to Hunger's "hoglike consumption" in Public Piers Plowman: Modern Scholarship and Late Medieval Culture (University Park: Penn State Press, 2004), 138. However, the association of pigs and insatiable appetite seems more a conceit of the modern imagination than the medieval which generally equated dogs with immoderate appetite.

${ }^{23}$ Fasciculus Morum, 629, 637. According to Juhani Norri, for instance, in the Middle English medical vocabulary bulimia and insatiable appetite are familiarly termed the "canine (dogges, houndes) appetit." See his "Entrances and Exits in English Medical Vocabulary, 1400-1550" in Medical and Scientific Writing in Late Medieval English, ed. Irma Taavitsainen et al. (Cambridge: Cambridge University Press, 2004), 125. Doubtless, the origin of the term "canine appetite" is Psalm 58:7.

24 "But, I ask, what shall we say of those who pretend to confess in Lent and right after Easter return to their sin 'as a dog returns to his vomit'? Verily, as much as it lies in them, 
its-vomit trope at 5.355, but with a twist in that Glutton's vomit smells so bad that even the hungriest hound in Hertfordshire won't lap it up. Covetise, on the other hand, is as hende as a hound in the kitchen because he won't share his food with anyone (5.257). The dog's reputation for a voracious appetite, a reputation which draws attention to its canine maw, is a central feature in several of Aesop's Fables, and thus it is no wonder that Aesop's figure for incorruptibility is the watchdog that refuses the bribe of food offered it by a thief. ${ }^{25}$ Another fable features a dog crossing a river with a bone in its mouth who, upon seeing its own shadow, loses what it has for certain in its mouth when it tries to grab the shadow's bone. This story in the Bestiary and Auctores Octo is glossed as signifying the foolish man who abandons salvation for the illusion of the material world. ${ }^{26}$ The author of Fasciculus Morum applies the figure of the dog's voracious eating habits to describe the fair weather friend and the deceitful child who treat people and parents well only to gain their material goods: "As a dog loves bones just for the meat on them; when he has eaten the meat, he leaves the bones in the dirt and no longer cares for them." ${ }^{27}$ Some details in Langland's description of Envy as a loveless dog (5.117) indeed recall Fasciculus Morum's illustration of this vice in two of its dog stories: the worm (of malice) under the dog's tongue

they crucify the Son of God a second time." Fasciculus Morum, 483; "When the dog returns to its vomit, it signifies those who fall into sin again after they have confessed." Bestiary, ed. Richard Barber (London: Folio Society, 1992), 77.

25 In Aesop's fable \#116, an egg-loving dog gulps down a shell-fish instead to its great discomfort. Fables \# 115, 118, 121, 122, and 123 also refer to the dog's appetite. The incorruptible watchdog is $\# 124$.

${ }^{26}$ The religious interpretation is even more explicit in Auctores Octo, the text of which can be readily accessed in Edward Wheatley's Mastering Aesop: Medieval Education, Chaucer, and his Followers (Gainesville: University of Florida Press, 2000), 215: "Allegoria: per carnem debemus intelligere regnum celeste. Per umbram transitoria huius mundi, per fluvium corpus cuiuslibet hominis. Non amittamus ergo perpetua gaudia de quibus certi sumus, id est regnum celorum quod nobis paratum est ab origine mundi. Fructus talis est: pro rebus transitoriis huius mundi non ammitamus eternam gloriam." [Allegorically, by the meat we ought to understand the heavenly realm, by the shadow the transitory nature of this world, and by the river the human body. Do not let the perpetual joys of heaven which have been prepared for us since the beginning of the world slip from our grasp. The moral is this: do not lose eternal glory for the transitory things of this world.]

${ }^{27}$ Fasciculus Morum, 195. 
which drives it to (back)biting and the dog's possessive love of the meat on bones which belong to someone else. ${ }^{28}$

The hungry hound, the dog as gaping maw into which food descends and out of which vomit spews only to be eaten again, is therefore a cultural trope so deeply ingrained in the medieval imagination that Langland need not say outright in literal words that the figure of Hunger in his poem is a hound because the association is beyond obvious. The trait which most identifies the canine nature of Hunger in Piers is the very fact that he is Hunger, the embodiment of the cultural trope inspired by Psalm 58's dog-like appetite, which becomes the vernacular medical term found in the writings of Gilbertus Anglicus and in Andrew Boorde's 1547 The Breuiary of Helthe:

There be .ii. kyndes of this infyrmyte [canyne/dogges appetyde] ... Yf it do come of a melancoly humour, a man shal haue a rauinyng stomake to eate whatsoeuer he can get. And whan the stomake is ful repleted, than it is trobled, and than the pacyent is prouoked to vomytinge. And after that the stomake is so euacuated or empty than the pacyent doth fall to eatynge agayne, and so consequently to vomytynge againe. There is another canyne appetyde, which is whan a man is euer hyngry and is neuer satisfyed, nor is nat well but whan he is eatynge or drynkynge. ${ }^{29}$

While Langland's Hunger does not overeat to the point of vomiting, he does demonstrate the canine appetite as described in Boorde's second order.

Yet as anyone at all familiar with the medieval system of signs would already suspect, the hound holds as well a wide variety of positive associations with which a moderately well-read medieval reader would

${ }^{28}$ Fasciculus Morum, 163 (backbiting), 195 (meat on bones). For further examples, see G. R. Owst, Literature and Pulpit in Medieval England, 2nd revised edition (Oxford: Blackwell, 1966), 451, 456-57.

${ }^{29}$ Andrew Boorde, The Breuiary of Helthe f.29r, quoted by Norri in "Entrances and Exits" at 125. A more restricted definition of hound's appetite as a vernacular medical term is found in Gilbertus Anglicus: "An vnresonable appetit is whan a man hap wille to ete aftir pat he hap eten rizt ynow. And per ben two kyndes of pis appetit. The toon is y-clepid an houndes appetit. And pat is whan a man etip moche more pen him nedip and sone aftir castip it vp as an hounde." See Healing and Society in Medieval England: A Middle English Translation of the Pharmaceutical Writings of Gilbertus Anglicus, ed. Faye Getz (Madison: University of Wisconsin Press, 1991), 156-57. 
be equally familiar. ${ }^{30}$ In the Bestiary, the dog is also touted as a model for rationality on the grounds that it can logically figure out the direction its prey went. ${ }^{31}$ If it can represent a demonic hound of hell, the dog can equally symbolize the righteous Christian. In Dives and Pauper, for instance, the proud lion is chastened by observing the beating of a little hound, a figure used to explain the corrective function of good men suffering in the world..$^{32}$ Again in Fasciculus Morum, the hunting dog is given the blood of its prey to lick so that it may more easily be drawn to the chase, an allegory for the true Christian's pursuit of Christ who "suffered and shed his blood for us [...] that he may draw us to his love and charity." ${ }^{33}$ In the Northern Homily Cycle, the Canaanite woman who pleads with Jesus to cure her daughter is likened in Matthew 15:21-28 to a heathen hound - a comparison that is implicit in the scriptural source which is the origin of the "heathen hound" insult-and she is also compared to a whelp blind for the first nine days of its life. ${ }^{34}$ Yet because she accepts her lowly status outside the ranks of the privileged and she holds true to her course of action out of love for her daughter, the dogwoman overturns the status quo and gains our admiration as a model of superlative Christian virtue, exhibiting ruth, patience, faith, constancy, righteousness, and meekness. As she gains insight when her puppy eyes open to the truth of Christian revelation, so she is rewarded through her daughter's restoration to health. These correspondences between the good Christian and the humble dog found scattered throughout other texts of the period recall Langland's own simile used to describe the begging poor left to suffer outside the gate of the privileged elite: "Is non to nyme hym in, nor his noy amende, / But hoen on hym as an hound and hoten hym go bennes" (10.60-61).

\footnotetext{
${ }^{30}$ Havelok, for instance, at line 1994 is compared favorably to a hound in relentless pursuit of a hare in the very same episode as the ruffians attacking him are called dogs.

31 "If a dog follows the track of a hare or a stag and comes to where the paths divide or to a crossroads, he will look silently at the ways and will decide rationally on the evidence of his keen sense of smell. Either the animal went this way, he says to himself, or that way, or it hid in this rocky cleft. But I know that it did not go in these directions, so it must have taken this path; by rejecting false trails he arrives at the truth" (Bestiary, 7).

32 Dives and Pauper, Volume I, Part 2, ed. Priscilla Heath Barnum (Oxford: Oxford University Press, 1980), 2.123.58.

${ }^{33}$ Fasciculus Morum, 205.

${ }^{34}$ The Northern Homily Cycle, ed. Anne B. Thompson (Kalamazoo: Medieval Institute, 2008), 108, 18.21-42; 110, 18.134.
} 
Yet even though the dog could represent the good Christian man or woman in general, the canine also held in the medieval imagination a more specific connotation as a signifier for the regular clergy. For instance, the three virtues of obedience, poverty, and chastity are treated allegorically as three hunting dogs by a certain preacher in his sermon upon the enclosure of a nun:

A literal hunter, as you know, needs certain things: hunting dogs, a collar, a leash, and a horn. In the same way, in order to hunt spiritually and to engage in this sport spiritually, this lady must have three hunting dogs, namely, obedience, poverty, and chastity. Let us not wonder that these virtues are likened to hunting dogs. For the Master of the Properties says that among the animals the dog is the most prudent, grateful, and faithful. Prudence is related to obedience, gratitude to poverty, and faithfulness to chastity. These dogs must have collars of good discretion. They must be led well with the leash of reason and be governed with the horn of good knowledge. ${ }^{35}$

As Siegfried Wenzel points out in his notes to this sermon, the preacher is clearly punning in specific fashion upon the lady's surname Huntingfield - to derive his lesson here, one which is pertinent to a lady about to enter into religious life. Yet while anyone of any estate can be prudent, grateful, and faithful and while anyone of any estate can exercise the virtues of obedience, poverty, and chastity, nonetheless these three virtues remain especially important to the regular clergy as the foundation of the three basic vows of religious life. These three hunting dogs point to a key clerical canine connection found in the general literature of the time period.

Likewise the Bestiary suggests a close association between the canine and the clerical: the dog's reputation for exemplary moderation and moral rectitude reflects the priest's position within society because "dogs are like preachers who by warnings and by righteous living turn aside the ambushes of the devil" and "the dog's way of life is said to be moderate, as he who is set above others must be watchful in the study of wisdom and avoid all kinds of inebriation." ${ }^{36}$ This would indeed seem to

\footnotetext{
${ }^{35}$ Siegfried Wenzel, ed. and trans., Preaching in the Age of Chaucer: Selected Sermons in Translation (Washington, D.C.: Catholic University of America Press, 2008), 292-93. The Master of the Properties is Bartholomaeus Anglicus, De proprietatibus rerum 18.24.

${ }^{36}$ Bestiary, 76.
} 
be the same dog that Langland admires as an animal that will not engage in inappropriate sexual intercourse with a pregnant bitch (11.343)! Even so, it must be observed that the canine connection to members of the clergy can occur in the negative too, as seen in the Revelation of the Monk of Eynsham where the dog-to-its-vomit trope applies specifically to clergy who have given up living according to their religious vows to return to the vomit of worldly existence. ${ }^{37}$

Another important metaphoric connection to the clergy is found in the dog's tongue, which in some texts is said to possess the marvelous ability to heal. ${ }^{38}$ First, there is the plant, hound's tongue, which is noted in the Old English Herbarium as a treatment for fever on the third or fourth day as well as shortness of breath. ${ }^{39}$ Likewise in Gilbertus Anglicus, hound's tongue figures as an ingredient in medical recipes to treat epilepsy, feeble sight, earache, and cough. ${ }^{40}$ Yet according to the Bestiary, the actual tongue of the dog literally holds this curative ability too: "A dog's tongue will heal a wound if he licks it .... The tongues of

\footnotetext{
37 "Religyous persons that were fugytyuys, that is to sey, that ranne oute of her order by the whiche they had bond hem-self to the seruice of God, and after turnid ageyne to the worlde and gaue hem to wordely leuing, as a dogge pat turnith ageyn to his vomet, so gretely they were there smyt with peynys pat $\mathrm{Y}$ can in no wise tell nethir declare her tormentis." The Revelation of the Monk of Eynsham, ed. Robert Easting (Oxford: Oxford University Press, 2002), 121, lines 2085-90.

${ }^{38}$ The belief in the curative power of the dog's tongue is ancient. For instance, in the cult of Asklepios at Epidaurus, the healing god is closely associated with dogs and there are several accounts of dogs successfully treating human wounds by licking them. See Louise Wells, The Greek Language of Healing from Homer to New Testament Times (Berlin: Walter de Gruyter, 1998), especially 32-35.

${ }^{39}$ The plant mentioned in the Old English Herbarium on 9 and 88 may be the same as cynoglossum officianale (hound's tongue, also known today as gypsy flower), although de Vriend points out in the explanatory notes to his EETS edition that there "is much uncertainty about the identity of this plant." See Old English Herbarium and Medicina de Quadrupedibus, ed. Hubert Jan de Vriend (Oxford: Oxford University Press, 1984), 298. Other medicinal "dog" plants that loosely associate the canine with concepts of healing are hound's head (snap dragon or toadflax), dog rose (rosa canina), hound's berry (black bryony), hound fennel (mayweed), hound's tooth (dandelion?), and horehound (also known as hound's weed and hound's bean). There is also the plant known in Old English as "hundescwelcan" - colocynth berries, which were used as a powerful purgative and, as the Old English name suggests, very poisonous. Medicina de Quadrupedibus lists several treatments which use various parts (or excretions) of the dog as an ingredient. See 264-66, 270-73. Likewise a dog's gall is cited by Gilbertus Anglicus as an ingredient in a treatment for epilepsy (Getz, 25). Hair of the dog, indeed!
}

${ }^{40}$ Getz, 25, 26, 61, 78, 116. 
puppies are a very good cure for wounds of the intestines." ${ }^{41}$ The notion that a dog's tongue can heal a wound points to a clerical connection because it suggests exegetical interpretations of Luke 16:19-31 in which dogs lick the wounds of the poor Lazarus begging outside the gates of Dives's mansion. ${ }^{42}$ That is, as the Bestiary goes on to gloss, the dog and its healing tongue can allegorize the priest and the saving power of the sacrament of penance: "As the dog's tongue heals a wound when he licks it, so the wounds of sin are cleansed by the instruction of the priest when they are laid bare in confession." 43 Thus when Anima in passus 15 advises clergy that perfect priests need to be "trewe of youre tonge and of youre tail bope" (15.105), through choice of this phrase Langland is cleverly punning on the canine undertones of the healing tongue and wagging tail description as much as he is demanding clerical adherence to the moderate, temperate rectitude that the dog-as-clergy is able to symbolize.

The canine as a polysemous sign explains why Langland chose the implicit portrayal of Hunger as Piers's watchdog in his poem: as a sign, the hound matches point for point the fundamental ambiguity, the wobble that Langland wanted for Hunger itself, because the hound can switch codes just as easily as Hunger can between being the good dog, loving and faithful St. Francis, and the bad dog, selfish and carnal Simon Legree. The author of Fasciculus Morum, for instance, happily uses exempla of good dogs and bad dogs, without any concern that the reader might become confused as to which valence is meant at any time. The author of the Bestiary is even more extreme in his switches, shifting between the good dog in one sentence and a bad dog in the next. The hound is driven to hunt, essentially an expression of its hunger. But the object hunted can describe an aim of spiritual desire as much as it can denote a carnal appetite or a material desire to consume. Just as importantly, the canine in the medieval imagination held a particular and strong association with the clergy - an association which shall prove instrumental in the delivery of Langland's ultimate message in passus 6.

\footnotetext{
${ }^{41}$ Bestiary, 76.

${ }^{42}$ Gregory the Great, for example, compared the dogs that licked the sores of Lazarus to the Church which heals the open wounds of sinners. The interpretation is well-established in patristic and medieval exegetical literature on which see Ferreiro, 155-81. In the C version of Piers Plowman, Hunger himself alludes to the Dives and Lazarus parable at C.8.278-82.

${ }^{43}$ Bestiary, 76.
} 
Langland himself certainly makes an obvious clerical canine connection elsewhere in Piers Plowman, and it is hard not to notice that in the immediate foreground he emphasizes its negative aspect. Clergie, for instance, accuses bad priests of being "doumbe houndis" unable to bark to raise the alarm about vice_- "canes non valentes latrare" (10.287$87 a$ ). Indeed, the link between dogs and the clergy in Piers Plowman is persistent and noteworthy in its adaptation of the particularly negative context of the canine. The hungry, thirsty poor at the gate are abused, while inside rich men and clerks "gnawen God wip pe gorge whanne hir guttes fullen" (10.57). ${ }^{44}$ Gnawen may strike the reader as a most peculiar choice of word on Langland's part, but in the context of the clerical canine gnawen's presence can immediately be accounted for: gnawen is there precisely because, like maw and tongue and tail earlier, it is yet another word loaded with canine suggestiveness. Dogs gnaw their food.

The episode also forms part of an unmistakable allusion to the Dives and Lazarus story, though it does not put the clerical canine into a positive light. Dogs-as-clergy are supposed to lick the wounds of Lazarus at the gate as they minister to the underprivileged sick and begging poor, but these clerical canines are too busy inside gnawing in comfort on more toothsome delights which like Covetise, they refuse to share. ${ }^{45}$ Other

44 This is another passage demonstrating editorial disagreement between Kane and Donaldson in the Athlone B edition and Schmidt in the Variorum Longman edition. The Athlone B edition at this point actually reads "gnawen god [in] pe gorge whanne hir gottes fullen" (B.10.58). Kane and Donaldson famously defend their emendation on the grounds that "gnawen wip pe gorge" is "actually nonsense" and a colourless substitution for the "appallingly graphic representation of blasphemy" which biting God persistently in the throat entails. See Kane and Donaldson, Introduction to Piers Plowman: The B Version, by William Langland (London: Athlone, 1975), 103. In Public Piers Plowman at 53, Benson points out, however, that no other Piers critic has accepted Kane and Donaldson's reading or interpretation at this point.

45 Even though the Doctor of Divinity in passus 13 is not explicitly identified in canine terms, he certainly exhibits the hound's appetite for food and drink (13.61-63) and he, like the hende hound Covetise, does not offer to share. The Doctor also has a link with Hunger and canine clericality through vomit: cf. Patience's comment on the Doctor's dining habits, "Vos qui peccata hominum comeditis, nisi pro eis lacrimas et oraciones effuderitis, ea que in delicijs comeditis, in tormentis euometis" (13.45a). Like Hunger whom the folk attempt to poison at 6.297, the Doctor seems to be a victim of poisoning, albeit self-inflicted food poisoning in his instance. And before a dog can return to eat its vomit, it needs after all to have cast up the contents of its stomach in the first place. Yet because Christ is another potential victim of toxic substances when he is offered "poison on a poole" to drink while he hangs on the Cross (18.52), in the same manner as Lady Meed who shadows Christ's buying of our pardon, the Doctor of Divinity's voracious eating habits also anticipate Christ's insatiable thirst in passus 18 . 
canine references are equally derisive when located in close proximity to clergy. Reason's sarcastic list of conditions under which he will show ruth upon Lady Meed at 4.124-25 includes when "bisshopes bayardes ben beggeris chaumbres, / Hire haukes and hire houndes help to pouere religious." And later on in passus 10, Clergie laments the current state of religion in the land as:

Ac now is Religion a rydere, a romere by stretes,

A ledere of louedayes and a lond buggere,

A prikere vpon a palfrey fro manere to manere,

An heep of houndes at his ers as he a lord were. (10.305-08)

The linkage of clergy and hounds is key in fact to a retroactive understanding of the significance behind Langland's choice of the otherwise seemingly bizarre figuration of Hunger in passus 6 as Piers's talking watchdog. Hunger's instruction to Piers is one of the deliberately homiletic sections of the poem and comparable to the speeches of Repentance and Scripture. Hunger's moral instruction on the importance of a moderate diet, a "lovely lessoun" as Piers describes it at 6.275, especially recalls Holy Church's earlier lecture on the subject. Notably, Hunger speaks and acts like a biblical scholar, offering glosses on seven different biblical texts very much in the vein of clerical discourse, actions which foreground the ability to speak and the possession of a tongue. Hunger, that is, is not only merely hunger as the logical, social consequence of too many wasters (by whatever paradigm these individuals may be identified) refusing to share the burden of labor for the common good, especially when some in the community feel entitled to hoard all the resources for themselves while others go without. But in a chain of metaphoric associations, Piers's dog is Hunger and Hunger is clergy. The resonance of the text thus goes far beyond the simple, literal message of work or starve, or the questionable ethics of calling upon Hunger to coerce cooperation out of a few for the greater common good, or a remarkable, if negative articulation of the principle of unintended consequences. ${ }^{46}$

It is not therefore strange that Piers should ask Hunger for advice on what to do about wasters and idlers in society because Hunger is demonstrably more than Piers's canine helper on the farm against the

\footnotetext{
${ }^{46}$ The "principle of unintended consequences" is Andrew Galloway's phrase in The Penn Commentary on Piers Plowman Vol. I (Philadelphia: University of Pennsylvania Press, 2006), 303.
} 
depredations of literal and metaphorical wolves. Hunger the dog links to Hunger the preacher, and hence he possesses the learning to sound off authoritatively with his clerical hound's tongue on moral and social matters. ${ }^{47}$ Hunger in sum is the very opposite of Clergie's later canine figure in passus 10, one taken from Isaiah 56:10 in which irresponsible priests are "doumbe houndis." Hunger in contrast acts as a clerical hound very much willing and able to bark, and his bite is considerably worse. Hunger's moralizing advice on moderation and beggary, wonderfully ironic in light of the rapacious clerical canines found elsewhere in the text and also his own insatiable canine appetite, plays on the dog's reputation in literature for exemplary conduct and on the wondrous powers of the hound's tongue to heal. The church is not therefore "entirely absent" from the Hunger episode, as Kate Crassons has claimed, ${ }^{48}$ and yet, to say the least, its function within a moral society seems highly compromised at this point in the text.

In the end, for all their malignant efforts to put an end to Hunger by poisoning him, ${ }^{49}$ the folk simply "garte Hunger go slepe" (6.300),

\footnotetext{
${ }^{47}$ While it may come across as authoritative, not everyone agrees that Hunger's clerical discourse is untainted. David Aers in Community, Gender, and Individual Identity argues that Hunger's arguments are designed to support the unfair status quo: "as Hunger anticipates, orthodox Christianity was to continue adapting to the employers' changing needs and ethos, in its moral teaching as in its exegesis. Langland, however, was sure that whatever texts could be mustered in support of Hunger's doctrine, labourers would continue to resist, rejecting the work ethos propagated by justices of the peace, employers, and orthodox clerics" (46). Ralph Hanna goes even further, accusing Hunger of blatant selfinterest: "In a context where Piers could be construed a sumptuous waster, and thus he and others should eat less (for their health, understand), there will be more surplus food about for Hunger himself to eat" (London Literature, 282).

${ }^{48}$ Crassons, The Claims of Poverty, 40.

${ }^{49}$ Intriguingly, the attempted poisoning of Hunger by the folk offers yet more, albeit obscure support for the Hunger-as-dog hypothesis in that, if the details are read literally, a human being cannot be poisoned by the means that the common folk adopt, though a dog can be: "Wip grene poret and pesen to poisone hym pei thozte" (6.297). Leeks (grene poret), like all members of the onion family, contain $\mathrm{N}$ propyl disulphide, a substance which is toxic to some animals, dogs included. Symptoms of $\mathrm{N}$ propyl disulphide poisoning in dogs include such classic signs as anemia, blood in the urine, vomiting, and cardiac arrhythmia. Left untreated, $\mathrm{N}$ propyl disulphide poisoning can result in the animal's death. I wish to thank my cat's veterinarian, Dr. Jay Thrush of the Brandon Hills Veterinary Clinic, Brandon, Manitoba, for confirming and expanding upon information about $\mathrm{N}$ propyl disulphide poisoning in dogs that I first discovered on the internet. However, Schmidt's reading poisone is not certain at 6.297 and the Athlone A and B versions read instead peisen (appease) at the equivalent line, on which see Kane's discussion on 449 in his critical notes upon the A-text edition. Additionally, of course, one is not obligated to read the details of the text literally.
} 
making him at this point not so much the figurative dumb hound of Isaiah 56:10 as the same verse's proverbial sleeping dog. ${ }^{50}$ Like many of the details in this scene, the significance of Hunger asleep can be read in various ways. First, it represents the temporary abatement of the literal, physical symptoms of hunger: with full bellies the folk no longer feel hungry, but the potential for hunger in the future is ominously still present, just sleeping for now. And indeed, there is the inevitable spiritual angle to the notion of sleeping Hunger too, as crass material comforts have dulled the desire, the hunger for spiritual advancement. But there remains an overlooked clerical and pastoral aspect to what is happening in the scene, one strongly suggested by Hunger's canineclergy associations and by the Isaiahan resonance of the metaphor, because as soon as the watchdog is not watching, the people quickly fall back into old sinful habits without the constant barking of their moral and spiritual guardian to protect the flock both from their own sheep-like habits and from the predation of wolves. This very point is made explicit in the C version of Piers Plowman at C.9.259-66 in terms which clearly connect the clergy, albeit once again in the negative, to the dog. In his explication of the terms of Truth's pardon, Piers warns bishops of the consequences of their ineffectual spiritual leadership:

For many wakere wolues ar wroken into thy foldes;

Thy berkeres aren as blynde that bringeth forth thy lombren -

Dispergentur oues, pe dogge dar nat berke.

The tarre is vntydy pat to be shep bylongeth;

Here salue is of supersedeas in sumnoures boxes.

Thy shep ben ner al shabbede, the wolf shyt wolle:

Sub molli pastore lupus lanam cacat, et grex

Incustoditus dilaceratur eo.

How, herde! where is thyn hound and thyn hardy herte,

For to go worye pe wolf that the wolle fouleth? (C.9.259-66)

A sleeping watchdog with its eyes closed or one blind to the presence of predators among the flock is as useless to a shepherd as a guard dog unable or too timid to bark. Both are figures for corrupt or irresponsible clergy who have lost the moral authority to lead. Hunger, sometimes awake and on guard against wolves at Piers's beck and call, and sometimes asleep and oblivious to their ravenous presence, handily

\footnotetext{
50 "His watchmen are all blind, they are all ignorant: dumb dogs not able to bark, seeing vain things, sleeping and loving dreams" (Isaiah 56:10).
} 
wobbles in Langland's text between the dual roles of responsible spiritual guardian and of incompetent, self-interested clergy. ${ }^{51}$

As with episodes and characters elsewhere in Piers Plowman, the Hunger episode reflects upon and anticipates other locations in the text. Some are obvious, such as how Conscience will later call upon Kynde to aid him in the defence of Unity against Antichrist (20.76-109) as Piers earlier did Hunger. Others are less evident, but further underscore the notion of Hunger's canine clericality. When Hunger attacks Waster and wrings him by the womb so hard that water comes out of his eyes, the laundry metaphor of wringing which describes the force of the attack anticipates Conscience's later use of the same metaphor in his equation of the Three Lives - Contrition, Confession, and Satisfaction - as three stages in the laundering of Haukyn's coat through the sacrament of penance (14.1-24) which, just like Hunger's temporary penitential effect on the people, is another process doomed to be a failure in the long term. Waster's watery eyes caused by Hunger's attack likewise echo at least the outward sign of the tears of Repentance at passus 5.60-61 and multiple locations elsewhere in the text. The confession scene of passus 5 of course is yet another scene in which the final result of the human penitential process led by a clergyman ends up an overall disappointment. The chain of watery references within the text connects the performance of the sacrament of penance to the wet and traditionallycleansing tongue of the dog, Hunger as priest.

But the laundry metaphor at 5.60, 6.175, and 14.1-24 pushes the bounds beyond the human and the steps in which the priest is involved because it also anticipates Anima's description in passus 15 of Charity's work ethic: his labor in a laundry:

${ }^{51}$ Though it does not distinguish between the identities of the good shepherd (Christ?) and the hound (the parish priest?) as personal agents, Robert of Brunne's Handlyng Synne illustrates the corrective pastoral role of the dog: "As pe gode shepard kepyp hys shepe, / So shalle pe prest, hys parysshenes kepe; / Pere shepe gone wrong besyde pe pap, / Pe shepard cryep for drede of skape; / And zyf bey wyl nat at hys crye / Turne azen to here pasture nye, / Pan settep he on hys hounde, / And baytep hem a wel gode stounde, / And bryngeb hem to her pasture weyl, / Ne slep he zyt none, neuer a deyl. / With pese prestes hyt shulde fare so, / whan here parysshenes oghte mysdo." Robert of Brunne's "Handlyng Synne," A.D. 1303 and Parts of its French Original I-II, ed. Frederick J. Furnivall (Millwood: Kraus Reprint, 1991), lines 10895-906. Handlyng Synne goes on to equate the hound on the abstract level to the "ordynaryys" of holy church (line 10909). That is, the priest is to keep his flock in line with canon law rather than through excommunication (cursing). 
And whan he is wery of pat werk pan wole he som tyme

Labouren in a lauendrye wel be lengbe of a mile,

And yerne into youpe, and yepeliche seche

Pride, wip al be appurtenaunce, and pakken hem togideres,

And bouken hem at his brest and beten hem clene,

And leggen on longe wip Laboraui in gemitu meo,

And wip warm water at hise eizen wasshen hem after. (15.186-92)

And ultimately the laundry metaphor points forward to Christ's vow in passus 18 that sinners "shul be clensed clerliche and clene wasshen of hir synnes / In my prisone Purgatorie, til parce it hote" (18.392-93) which describes at last a cleansing ritual that will hold forever. Another connection moreover exists between Christ in this passage and the earlier figure of Hunger from passus 6: both Hunger's insatiable canine appetite and his refusal to depart before he has "dyned by pis day and ydronke bope" (6.278) clearly anticipate the endless thirst of Christ for the salvation of human souls:

For I pat am lord of lif, loue is my drynke,

And for pat drynke today, I deide vpon erpe.

I fauzt so, me purstep yet, for mannes soule sake;

May no drynke me moiste, ne my purst slake,

Til pe vendage falle in pe vale of Iosaphat,

That I drynke rizt ripe must, resureccio mortuorum.

And panne shal I come as a kyng, crouned, wip aungeles,

And haue out of helle alle mennes soules. (18.366-73)

Though the focus is switched from an obsession with food to an endless desire for drink, Christ too appears to suffer from the voracious hound's appetite. ${ }^{52}$ As Hunger by definition cannot ever eat and drink enough to satisfy his appetite and he must therefore either fall asleep at the table under the influence of strong beer or else follow his own good advice to get up and leave while still hungry (6.263), Christ too is pictured as suffering from a thirst that he cannot quench: he wants for himself not just some of the souls of mankind, he craves all of them and he will not

\footnotetext{
52 Dante's enigmatic greyhound in Canto 1 of Inferno, lines 100-11, affords somewhat of a parallel, although insatiable appetite is more a quality of the she-wolf than of the greyhound which will some day kill her. The greyhound's appetite is marked instead by abstraction: "Questi non ciberà terra né peltro, / ma sapïenza, amore et virtute" [He will not feed on earth or pelf, / but on wisdom, love, and virtue]. Dante Aligheri, The Divine Comedy, Inferno I: Italian Text and Translation, ed. and trans. Charles S. Singleton (Princeton: Princeton University Press, 1970), Canto 1, lines 103-04.
} 
share his drink with the devil. ${ }^{53}$ And even the threatened poisoning of Hunger fits into the Christology of the poem, because poison is offered to Christ on the cross at 18.52 and because Christ the drink of love exists in triumphant opposition to the Arch-Poisoner Lucifer's brew. ${ }^{54}$

What then is to be made of Hunger the Dog in Piers Plowman? In the end, recognition that Hunger is Piers's dog in Langland's text heightens our understanding of the multiple ambivalences of this passage and their importance to understanding Piers Plowman as a whole. Hunger is the embodiment of the cultural trope of the dog-like appetite which can be good or bad, and hence he can fulfill within the text many contradictory roles because these various parts resonante upon the several ways in which the dog as sign was generally regarded in the medieval period. Hunger is, first, the crass and literal physical hunger, the dog-like appetite to consume selfishly, a hunger which never entirely goes away and which is constantly at odds with the human reluctance to work. Yet it is secondly the abstract hunger which drives one to hunt for spiritual fulfillment, another dog-like hunger which cannot be satisfied while here on earth. Hunger also serves in a third role as a negative figure for clerical corruption and perhaps, as Aers has suggested, for an all-tooready willingness to skew the interpretation of biblical texts to cover for the endless rapacity of the social elite, certainly for clerical greed and carnality on many levels; and yet at the same time Hunger serves equally

\footnotetext{
53 Note the insistent repetition on "all" in statements uttered by Christ that certainly seem to amount to bold declarations of universal salvation: " $O$ vos omnes sicientes, venite" (11.120a); "I clayme / Adam and al his issue at my wille herafter" (18.344-45); "Adam and alle pour3 a tree shal turne to lyue" (18.360); "And mercy al mankynde bifore me in heuene" (18.398). Christ may leave behind the souls of the wicked at the Harrowing of Hell, but he warns Lucifer that he plans to come back and "haue out of helle alle mennes soules" (18.373) at Judgement Day. The idea of universal salvation had contracted considerably since Gregory of Nyssa in the fourth century had it include the Devil. For recent discussions of universal salvation in Langland, see Thomas Hill, "Universal Salvation and its Literary Context in Piers Plowman B18," Yearbook of Langland Studies 5 (1991), 65-76; Nicholas Watson, "Visions of Inclusion: Universal Salvation and Vernacular Theology in Pre-Reformation England," Journal of Medieval and Early Modern Studies 27 (1997), 145-87; Kathryn Kerby-Fulton, Books Under Suspicion: Censorship and Tolerance of Revelatory Writing in Late Medieval England (Notre Dame: University of Notre Dame Press, 2006), 358-83; and David Aers, Salvation and Sin: Augustine, Langland, and Fourteenth-Century Theology (Notre Dame: Notre Dame University Press, 2009), 115-19.

54 Hunger and Christ in Piers Plowman share at least one further attribute in common: the power to cure blindness. Compare B.6.191-92 and B.18.78-96. Hunger's ability to cure the blind, of course, is not meant to be literally understood since Langland's tone at 6.19192 is clearly sarcastic.
} 
well in a fourth capacity as a positive emblem for the spiritual guardianship of the clergy, of Hunger as Piers's faithful watchdog over the sheep, and as a reflective anticipation of Christ's own insatiable doglike thirst for human souls.

Brandon University 


\section{Bibliography}

Adams, Gillian. "A Medieval Storybook: The Urban(e) Tales of Petrus Alfonsi." Children's Literature Association Quarterly 23, no. 1 (1998): 7-12. http://dx.doi.org/10.1353/chq.0.1167

Aers, David. Community, Gender, and Individual Identity: English Writing, 1360-1430. London \& New York: Routledge, 1988.

—. Salvation and Sin: Augustine, Langland, and Fourteenth-Century Theology. Notre Dame: Notre Dame University Press, 2009.

Aligheri, Dante. The Divine Comedy, Inferno I: Italian Text and Translation. Edited and translated by Charles S. Singleton. Princeton: Princeton University Press, 1970.

Austin, R. G., ed. P. Vergili Maronis Aeneidos, Liber Sextus. Oxford: Clarendon Press, 1977.

Barber, Richard, ed. Bestiary. London: Folio Society, 1992.

Barnum, Priscilla Heath, ed. Dives and Pauper Volume I, Part 2. Early English Text Society 280. Oxford: Oxford University Press, 1980.

Benson, C. David. Public Piers Plowman: Modern Scholarship and Late Medieval Culture. University Park: Penn State Press, 2004.

Bevington, David, ed. Medieval Drama. Boston: Houghton Mifflin, 1975.

Bloomfield, Morton. The Seven Deadly Sins: An Introduction to the History of a Religious Concept, with Special Reference to Medieval English Literature. Ann Arbor: Michigan State University Press, 1952.

Boorde, Andrew. The Breuiary of Helthe. London: W. Myddleton, 1547; Facsimile edition: English Experience 362. New York: Da Capo Press, 1971.

Bowers, John. The Crisis of Will in Piers Plowman. Washington, D.C.: Catholic University of America Press, 1986.

Chaucer, Geoffrey. The Riverside Chaucer. Edited by Larry D. Benson. 3rd edition. Boston: Houghton Mifflin, 1987.

Crassons, Kate. The Claims of Poverty: Literature, Culture, and Ideology in Late Medieval England. Notre Dame: Notre Dame University Press, 2010. 
DuBruck, Edelgard. “Aesop's Weeping Puppy: Late Medieval Migrations of a Narrative Motif." The Early Drama, Art, and Music Review 22, no. 1 (1999): 1-10.

Easting, Robert, ed. The Revelation of the Monk of Eynsham. Early English Text Society 318. Oxford: Oxford University Press, 2002.

England, George, and Alfred W. Pollard, ed. The Towneley Plays. Early English Text Society E.S. 71. Reprint of 1897 edition. London: Oxford University Press, 1966.

Ferreiro, Alberto. Simon Magus in Patristic, Medieval and Early Modern Traditions. Leiden: Brill, 2005.

Furnivall, Frederick J., ed. Robert of Brunne's "Handlyng Synne," A.D. 1303 and parts of its French Original. Early English Text Society O.S. 119, 123. 1901 and 1903 editions reprinted as one volume, Millwood: Kraus, 1991.

Galloway, Andrew. Penn Commentary on Piers Plowman Vol. I. Philadelphia: University of Pennsylvania Press, 2006.

Getz, Faye, ed. Healing and Society in Medieval England: A Middle English Translation of the Pharmaceutical Writings of Gilbertus Anglicus. Madison: University of Wisconsin Press, 1991.

Ginsberg, Warren, ed. Wynnere and Wastoure and The Parlement of the Thre Ages. Kalamazoo: Medieval Institute Publications, 1992.

Handford, S. A., ed. and trans. Fables of Aesop. Harmondsworth: Penguin, 1964.

Hanna, Ralph. London Literature: 1300-1380. Cambridge: Cambridge University Press, 2005.

Harwood, Britton J. Piers Plowman and the Problem of Belief. Toronto: University of Toronto Press, 1992.

Hewett-Smith, Kathleen. "Allegory of the Half-Acre: The Demands of History." Yearbook of Langland Studies 10 (1996): 1-22. http://dx.doi.org/10.1484/J.YLS.2.302800

Hill, Thomas. "Universal Salvation and its Literary Context in Piers Plowman B18." Yearbook of Langland Studies 5 (1991): 65-76. http://dx.doi.org/10.1484/J.YLS.2.302896

Justman, Steward. "The Secularism of Fiction: A Medieval Source." Literary Imagination 10, no. 2 (2007): 127-41.

http://dx.doi.org/10.1093/litimag/imm112

Kane, George. Piers Plowman: Glossary. London and New York: Continuum, 2005. 
Kerby-Fulton, Kathryn. Books Under Suspicion: Censorship and Tolerance of Revelatory Writing in Late Medieval England. Notre Dame: University of Notre Dame Press, 2006.

Kim, Margaret. "Hunger, Need and the Politics of Poverty in Piers Plowman." Yearbook of Langland Studies 16 (2002): 131-68. http://dx.doi.org/10.1484/J.YLS.2.302646

Kuhn, Sherman M., and John Reidy, ed. The Middle English Dictionary: Part M.2. Ann Arbor: University of Michigan Press, 1975.

Langland, William. Piers Plowman: The A Version, Will's Visions of Piers Plowman and Do-Well, an edition in the form of Trinity College Cambridge MS R.3.14 corrected from other manuscripts, with variant readings. Edited by George Kane. London: Athlone, 1960.

- Piers Plowman: The B Version, Will's Visions of Piers Plowman, Do-Well, Do-Better and Dobest, an edition in the form of Trinity College Cambridge MS B.15.17, corrected and restored from the known evidence, with variant readings. Edited by George Kane and E. Talbot Donaldson. London: Athlone, 1975.

- Piers Plowman: A Parallel-Text Edition of the A, B, $C$ and $Z$ Versions, Vol. I: Text. Edited by A. V. C. Schmidt. London and New York: Longman, 1995.

- The Vision of Piers Plowman: A Critical Edition of the B-Text based on Trinity College Cambridge MS B.15.17. Edited by A. V. C. Schmidt. 2nd edition. London: J. M. Dent, 1995.

Mann, Jill. "Eating and Drinking in Piers Plowman." Essays and Studies 32 (1979): 26-43.

Norri, Juhani. "Entrances and Exits in English Medical Vocabulary, 1400-1550." Medical and Scientific Writing in Late Medieval English. Edited by Irma Taavitsainen and Päivi Pahta. Cambridge: Cambridge University Press, 2004.

Owst, G. R. Literature and Pulpit in Medieval England. 2nd revised edition. Oxford: Blackwell, 1966.

Pearsall, Derek. "Piers Plowman and the Problem of Labour." In The Problem of Labour in Fourteenth-Century England, edited by James Bothwell, P. J. P. Goldberg, and W. M. Ormrod,123-32. York: York Medieval Press, 2000.

Resnick, Irven M. "Good Dog/Bad Dog: Dogs in Medieval Religious Polemics.” Enarratio 18 (2013): 70-97. 
Robertson, Jr, D.W., and Bernard Huppé. Piers Plowman and Scriptural Tradition. New York: Octagon Books, 1969. Reprint of 1951 edition.

Sands, Donald, ed. Middle English Verse Romances. Exeter: University of Exeter Press, 1986.

Thompson, Anne B., ed. The Northern Homily Cycle. Kalamazoo: Medieval Institute, 2008.

Tolkien, J.R.R. and E.V. Gordon, ed. Sir Gawain and the Green Knight. 2nd edition edited by Norman Davis. Oxford: Clarendon, 1977.

Trower, Katherine. "The Figure of Hunger in Piers Plowman." American Benedictine Review 24, no. 2 (1973): 238-60.

Vriend, Hubert Jan de, ed. Old English Herbarium and Medicina de Quadrupedibus. Early English Text Society 286. Oxford: Oxford University Press, 1984.

Watson, Nicholas. "Visions of Inclusion: Universal Salvation and Vernacular Theology in Pre-Reformation England." Journal of Medieval and Early Modern Studies 27 (1997): 145-87.

Wells, Louise. The Greek Language of Healing from Homer to New Testament Times. Berlin: Walter de Gruyter, 1998. http://dx.doi.org/10.1515/9783110822038

Wenzel, Siegfried, ed. and trans. Fasciculus Morum: A FourteenthCentury Preacher's Handbook. University Park: Penn State Press, 1989.

Wenzel, Siegfried, ed. and trans. Preaching in the Age of Chaucer: Selected Sermons in Translation. Washington, D.C.: Catholic University of America Press, 2008.

Wheatley, Edward. Mastering Aesop: Medieval Education, Chaucer, and his Followers. Gainesville: University of Florida Press, 2000.

Whitelock, Jill, ed. The Seven Sages of Rome (Midland Version). Early English Text Society 324. Oxford: Oxford University Press, 2005.

Zeeman, Nicolette. Piers Plowman and the Medieval Discourse of Desire. Cambridge: Cambridge University Press, 2006. 